insect relationship to food plants is dictated by token or nutrient stimuli, whether oligophagy is based on attraction or repulsion and whether taste or smell is more important. Bohavioural, and particularly physiological, experiments seem to indicate that all these factors are involved. 'The inflow of data to the central nervous system relating to stimulation by food plant substances is complex, and hence neither the mochanism of discrimination nor the basis of preference can be a simple one. Prof. Dethier pointed out that the regulation of the initiation, termination and frequency of feeding had received less attention than the problem of selection. In some insects, for example the fly, the process is driven by sensory input and is terminated by sonsory adaptation, while the frequency of feeding is controlled by an as yet unknown mechanism; on the othor hand, in other insects such as the locust, endogonous central activity appears to influence the initiation of feeding.

Dr. A. Manning (Edinburgh) described sexual behaviour and defined it as "specialized behaviour" patterns which form tho normal preliminaries to mating". He pointod out that elaborate soxual behaviour occurs in some insects but not in others and raised tho problem of 'female coyness'. He considered three possible functions of courtship: appeasement and synchronization, physiologicul maturation, and sexual isolation, and concluded that various combinations of the foregoing functions must have been involved in the evolution of 'female coyness'. Ho felt that a direct origin of the movements used in courtship from modified pre-copulation movements was often plausible, and pointed out that the ritualism of insect sexual behaviour had followed a course vory similar to that found in vertebrates. As to the organiza. tion of soxual behaviour, he emphasized that the data were so meagre that little generalization could be made, but that sexual behaviour seems to depend more on the sex of the brain than on that of the lower centres.

Dr. J. D. Carthy (London) spoke on insect communication, which could be said to occur whonever a sensory signal caused a change in the behaviour of an animal. He pointed out that in most cases the receiver is informed of the physiological state, the sex, the species and often the position of the sendor, that the language is often private to the species and that dialects may occur which are specific to a group of individuals in a neighbourhood. $\mathrm{Ho}$ examined the range and type of visual, acoustic, tactile and chemical communication and brought forward examples showing how these may be combined to increasse the total sum of information passed.

Prof. E. O. Wilson (Harvard), in doaling with the behaviour of social insects, deliberately minimized the functional aspects of this behaviour in order to pay close attention to theoretical considorations of its $\theta$ volution. In examining its origin, he supported the viow of Hamilton that true sociality, mostly limited to the Hymenoptera, had arisen because of the haplo-diploidy provalent in that order, which, since it resulted in grcater genetic similarity between siblings than between parents and offspring, favoured the development of altruistic bchaviour. Sociality in the termitos, he felt, was associated with obligatory protozoan symbiosis, thus taking the view that true sociality was made possible through pre-adaptations which themselves had nothing to do with sociality. Prof. Wilson went on to examine fitness in insect societies and indicated, for oxample, that worker inefficiency, including mass behaviour that is the opposite of social facilitation, is widespread in the social insects and yot makes a positive contribution to colony fitness. On balance, howevor, ho concluded that the question of altruism above the individual level remains opon.

The final paper was given by Dr. J. S. Kennedy (Cam. bridge $\theta$ and the arrangements for this were of an oxperimental nature in that . Dr. Kennedy was asked to talk on "Some Outstanding Questions in Insect Behaviour", drawing largely on points raisod by the preceding speakers and thus promoting wide-ranging general discussion to end the symposium. Dr. Kennedy treated four main topies: tho origin of social behaviour, communication and 'female coyness', orientation behaviour, and the control of responsiveness. As regards the origins of social behaviour Dr. Konnedy disagreed with Prof. Wilson and suggested that the long-standing theory of parental care as the basis of social behaviour was still adequate. The onsuing lively discussion touched on the value of parental care, the influence of food-sharing, the significance of symbiosis and tho ovolution of altruistic and selfish behaviour. On balance, while it was conceded that the phenomena of haplo-diploidy and symbiosis may have played some part, parental care won the day as being likely to afford a sufficient basis for the evolution of sociality.

As regards 'female coyness', Dr. Konnedy asked if this was widespread and enquired whether 'male coyness' was also involved, and whether in any case the term was not a misinterpretation of the delaying function of tho behaviour which may be necessary so that both males and females can complete internal processes essential to mating. The discussion emphasized the paucity of data on the subject, although the interesting suggestion was made that there was selectivo value to the behaviour if it was considered as an extension to normal pre-copulatory communication which ostablishes specific recognition.

On orientation, Dr. Kennedy asked whether tho system of Jander did in fact correspond to the 'natural structure' of the behaviour; the discussion did not elucidate this point and served to emphasize the continuing lack of any adequate structure for the classification of insect behaviour.

The final problem discussed by Dr. Kennedy was the control of responsiveness in insects in various behavioural situations, and raised the important issue of the soparation of endogenous activity, or 'drive', from reflex activitythe stimulus-response systom. The general tenor of the discussion was that the past approach to this problem, based on an 'either-or' choice of these two concepts, had been misleading; the actual system probably involved characteristics of both.

All tho papers and the ensuing discussions are to be published shortly in a fully bound volume by the Royal Entomological Society.
P. T. Haskeli

\title{
FOREST NURSERIES
}

$\mathrm{F}$ OREST nurseries became important in British forcst practico with the introduction of exotic conifers in the latter part of the eighteenth contury for large-seale reforestation work on private estates. But thoy assumod even groater importance after the crestion of the Forestry Commission in 1919 with its declared policy of afforesta tion. At the present timo the plant requirements of the State forost service and of private estates and commercial enterprises are enormous and nursery practice has become a scientific matter. This has developed greatly in tho past twenty years. Before that, nurseries were mainly the agricultural type whoro fertility was maintained by farmyard manure in somo cases but mainly by ploughing-in green crops and the use of fallows and rotational practice. However, it was found that the bost conditions were not being obtained for growing coniforous seedlings. These were required in greater quantities than ever and in less timo than the usual 3-4 years to produce a plant suitable for afforestation purposes. Some exporimental work had been done by the Forestry Commission, but in 1944 it 
was decided to set up a "Sub-Committee on Nutritional Problems in Tree Nurseries" the terms of reference of which were "to assess the problems underlying the nutrition of forest trees in nurseries and to suggest any desirable extensions already in progress".

The account of the work carried out between 1945 and 1962 by a joint research effort between staff of the Rothamsted Experimental Station and the Research Branch of the Forestry Commission is embodied in Forestry Commission Bulletin No. 37 *.

Volume 1 comprises the text and the main tables and Volume 2 contains detailed supporting tables, but this second volume is not needed for reading the first. The initial volume contains three main parts. First, there is a historical account of nursery practice in Britain since the 1920's. The objects and scope of the investigation are defined and notes are provided on sites and experimental methods. The second part, and by far the largest,

* Forestry Commission. Bulletin No. 37. Experiments on Nutrition prablems in forest Nurseries. By Blanche Benzian. Vol. 1. Pp. Xi $+251+25$
plates. 50s. Vol. 2. Pp. v+265. 20s, net. (London: H.M.S.O., 1965.) is concerned with seed-bed experiments and these are well described and supported by adequate tables. The third part deals with experimental work on transplants and this required extension experiments.

Histories of individual nursery sites and notes on sylvicultural techniques are included in the appendix and there are useful supplementary papers on microfauna and microflora. There are eight pages of coloured plates and they can only be described as superb. They bring out in a most certain way what each plate is meant to show. Indeed, the whole publication maintains that high standard associated with Forestry Commission bulletins.

Volume 2 will have a limited demand, but Volume 1 is a valuable contribution to the understanding of forest nursery problems and to the improvement of techniques in raising young trees for afforestation and re-forestation purposes. As planting is likely to be the means most used for many years to come in regenerating Britain's forests, it is obvious that good forest nursery practice is of the greatest importance.
C. J. TAYLOR

\section{PERUGIA UNIVERSITY MEDICAL SCHOOL NEW LECTURE HALL OF PATHOLOGY \\ BY PROF. LUCIO SEVERI \\ Director, Institute of Morbid Anatomy}

$\mathrm{O}$ N June 27, 1965, Lord Florey, president of the Royal Society of London and Provost of Queen's College, Oxford, opened the new Lecture Hall of Pathology in Perugia, Monteluce. At the same time he delivered the first Cesare Massari lecture entitled "The Anatomy and Physiology of Small Blood Vessels".

The ceremony was attended by the Magnifico Rettore of Perugia University, members of the Perugia University Medical School, participants in the third Perugia quad. rennial international conference on cancer ("Lung Tumours in Animals"), and other distinguished guests from many Italian universities.

\section{Science in Perugia}

It Italy, as elsewhere, there is an ever-growing and deeply felt concern about the training of scientists and technologists. In Perugia, sciontists and technologists are graduating in large numbers, certainly in greater numbers than at any other time. These numbers, however, are not satisfactory, since scientists and technologists comprise only about one-third of the student populationthe lowest point of a progressive percentage decrease over the past 26 years. The numbers of students in pharmacy, agriculture and veterinary medicine are not increasing, although these faculties are traditional in the University of Perugia; however, the Faculty of Science, founded during the academic year 1951-52, is stoadily developing. It is difficult to give figures, as classification is, to some oxtent, subjective, especially in a university where every. one has his own ideas on how disciplines should be grouped together. Nevertheless, Table 1 gives some figures.

Of the figures given in Table 1, scientists represent the proportions shown in Table 2.

\section{Medicine in Perugia}

The Perugia University Medical School is fortunate: although it is situated within the city boundaries, it lies on Monteluce hill (1,500 ft. above sea-level) facing east; it dominates the valley of the Tiber and looks on to Assisi and the Appenines (snow-capped for the greater part of the year). The development of medical studies has followed a normal pattern, as can be seen from Table 3.
The Medical School has steadily expanded its facilities since the end of the Second World War. New buildings have been provided for those departments dealing with general pathology and morbid anatomy, orthopaedics, paediatrics (with a Poliomyelitis Department), surgery and dentistry. A large six-storeyed block has been built for the Institutes of Biology, Physiology, Anatomy, Pharmacology, Forensic Medicine and Hygiene. Small lecture rooms have been set aside for seminars and tutorials in each Institute and there is a large common lecture hall sufficient for 300 students. Probably the most interesting development in the field of research in the Perugia Medical School has been the growth of the Division of Cancer

\begin{tabular}{|c|c|c|c|}
\hline & Undergraduate & Postgraduate & Total \\
\hline 1938-39 & 615 & 一 & 615 \\
\hline $1949-50$ & 2,558 & - & 2,558 \\
\hline $1954-55$ & 2,606 & 86 & 2,692 \\
\hline $1959-60$ & 3,906 & 289 & 4,195 \\
\hline $1964-65$ & 6,130 & 248 & 6,378 \\
\hline
\end{tabular}
1954-55, 1959-60 and 1964-65.

$\begin{array}{lcccrrr} & \text { I } & \text { II } & \text { III } & \begin{array}{c}\text { Total } \\ \text { scientists }\end{array} & \begin{array}{c}\text { Total } \\ \text { students }\end{array} \\ & & & & & & \begin{array}{c}\text { Total scientists } \\ \text { expressed as a } \\ \text { percentage of } \\ \text { total students }\end{array} \\ 1938-39 & - & 263 & 201 & 464 & 615 & 75 \cdot 4 \\ 1949-50 & - & 1,242 & 464 & 1,706 & 2,558 & 66 \cdot 7 \\ 1954-55 & 142 & 1,019 & 346 & 1,507 & 2,692 & 56 \cdot 0 \\ 1959-60 & 273 & 1,090 & 337 & 1,700 & 4,195 & 40 \cdot 5 \\ 1964-65 & 496 & 1,356 & 315 & 2,167 & 6,378 & 34 \cdot 0 \\ \text { Group I. Students in mathematical, physical and biological sciences, } \\ \text { with degrees in biological sciences, natural sciences and chemistry. } \\ \text { Group II. Students in medical sciences (including medicine, pharmacy } \\ \text { and veterinary medicine). } \\ \text { Group III. Students in agriculture. }\end{array}$

Table 3. STUdents IN MEdicine
Undergraduate Postgraduate

1938-39

1949-50

1954-55

1959-60

1964-65

$\begin{array}{lr}177 & - \\ 579 & - \\ 617 & 86 \\ 607 & 289 \\ 842 & 248\end{array}$

Total

177

579

703
896

1,090 